\title{
ARQUEOLOGIA HISTÓRICA. POR QUE O PASSADO IMPORTA
}

\section{Historical Archaeology. Why the past matters}

Martha Helena Loeblein Becker Morales*

LITTLE, Barbara J. Historical Archaeology. Why the past matters. Walnut Creek, California: Left Coast Press, 2007.

Barbara Little é uma prolífica autora de publicações na área da Arqueologia Histórica, mais recentemente destacando temas da Arqueologia Pública, com interesse especial na gestão do patrimônio. Professora adjunta no Departamento de Antropologia da Universidade de Maryland, desempenhou também papel importante em decisões acerca da legislação federal norte-americana de proteção ao patrimônio arqueológico.

O livro aqui resenhado, publicado em 2007 e premiado no ano seguinte pela Choice: Current Reviews for Academic Libraries, apresenta uma importante contribuição ao estudo do passado devido não só à reflexão de cunho mais teórico desenvolvida pela autora, mas também aos exemplos por ela selecionados na forma de estudos de caso, com seus problemas pontuais e eventuais soluções. A narrativa foi dividida em quatro macrosseções, a saber: Quais são as nossas ambições?; Com o que nos importamos?; Um levantamento panorâmico da Arqueologia Histórica; e Arqueologia Histórica como erudição pública. A escolha pelo uso da primeira pessoa do plural nos questionamentos que guiam o texto se deve ao direcionamento claro de suas palavras ao grupo formado pelos arqueólogos, principalmente aqueles preocupados com o período dito "histórico", mas acredito que a leitura se mostre instigante a qualquer estudioso que tome o passado como objeto construído no presente.

" Programa de Pós-Graduação em História da Universidade Federal do Paraná, sob orientação da Prof. Dra. Renata Senna Garraffoni. Bolsista do Programa REUNI de Assistência ao Ensino. 
Já em seu prefácio somos informados de que a motivação de sua escrita está na percepção de que se fala muito que o valor da história está em aprender com o passado, embora poucas vezes isto aconteça de fato. Incomodada pelas formas como o passado é utilizado para manter posições de intolerância, injustiça e desigualdade, Little se propõe pensar na Arqueologia Histórica, um amálgama da História e da Arqueologia, como uma possibilidade excepcional para desafiar certezas naturalizadas, por meio de novas combinações de evidências. Quanto a isso, é importante destacar que em vários momentos de seu texto são ressaltadas as especificidades de cada uma das disciplinas, mas também recebe destaque o quanto seu trabalho conjunto tem a contribuir com as questões públicas emergentes na atualidade. A autora faz, em suma, uma leitura otimista das alternativas oferecidas pela Arqueologia Histórica, alinhando-a, por vezes, às ambições democratizantes das histórias dedicadas a trazer à luz os excluídos.

A primeira seção conta com sete capítulos, dedicados às ambições dos arqueólogos históricos. Este é um campo de pesquisa associado, pela autora, a uma espécie de Antropologia Aplicada, uma vez que haveria uma preocupação direta em aplicar quaisquer lições aprendidas aos problemas do "mundo real", levando sempre em conta as necessidades dos muitos públicos que poderão vir a valorizar e fazer uso dos resultados. É uma perspectiva bastante próxima da aventada pela Arqueologia Pública, com suas propostas de visualização dos passados multivocais.

Entre os vários objetivos e metas que Little aponta como fundamentais à Arqueologia Histórica, alguns são mais aprofundados. Em primeiro lugar, a autora trata da utilização desta disciplina em estudos de identificação, preservação e interpretação de sítios arqueológicos, em especial os de interesse arquitetônico, destacando a legislação e regulamentação pública de salvaguarda patrimonial como responsável pelo crescimento do mercado profissional dos arqueólogos históricos norte-americanos.

Em seguida, num diálogo mais claro com o viés histórico da disciplina, preocupa-se em esclarecer a necessidade de reformular as perguntas e interpretações, a fim de evitar o que no passado se mostrou uma rasa relação complementar entre os vestígios materiais e a documentação escrita. Sua proposta é de refinamento do saber que se constrói acerca do passado, algo inviabilizado pela contraposição que visa apenas "desmentir" o que uma ou outra evidência aponta. Mais do que isso, Little percebe o 
quanto é possível conhecer sobre as diferentes pessoas que compuseram as sociedades passadas, uma vez que se compreendam processos regionais e globais como o colonialismo, o capitalismo e a escravidão. Este é, inclusive, um ponto crucial em seu raciocínio - seria o estudo do desenvolvimento do mundo moderno uma particularidade da Arqueologia Histórica, algo salientado inúmeras vezes por vários outros autores, como Paul Shackel, Charles Orser Jr. e Mary Beaudry.

Entrando na segunda seção do livro, a autora permanece nesta questão do estudo do mundo moderno como parte da identidade da Arqueologia Histórica, ainda que não unânime, e ressalta a importância de refutar a percepção de que a "história" veio em navios europeus para a América em 1500. Para tanto, a quebra da dicotomia acadêmica pré-história $X$ história, bem como arqueologia pré-histórica $\mathrm{X}$ arqueologia histórica, seria um passo fundamental. Somente assim, procurando pelos silêncios culturalmente impostos, a interpretação do passado alcançaria novos horizontes.

Nesta segunda seção, voltada aos interesses dos arqueólogos históricos, Little problematiza ao longo de seis capítulos os posicionamentos subjetivos que definem o trabalho com o passado. Dessa forma, reconhece que, embora muitos temas se mantenham como escolhas populares, o recorte específico da investigação traz alguma variedade aos resultados. Além disso, a autora observa um crescente interesse no século XX, algo impensável na disciplina há cinquenta anos. Seria, portanto, este interesse por problemáticas cada vez mais atuais o responsável pela associação do campo aos estudos do capitalismo, do colonialismo e da escravidão.

Igualmente, não foi apenas o recorte temporal que se expandiu, mas a própria noção de cultura material, um conceito sempre complexo. Antes limitado a artefatos fragmentados e descartes recuperados na subsuperfície, agora a cultura material abrangeria documentos escritos encontrados em arquivos públicos e privados, obras de arte presentes nos museus, jardins e paisagens abertas, conjuntos arquitetônicos, ruas, entre tantos outros. Contudo, abre-se um questionamento com relação à necessidade da escavação, um trabalho próprio da arqueologia, frequentemente custoso, que agora se faria desnecessário. A respeito disso, Little contra-argumenta em nome de uma relativização de tal questionamento: a noção de contexto arqueológico precisa ser repensada, em paralelo, para que não mais se limite às unidades escavadas, níveis e características estratigráficas de sempre. 
Outro ponto realçado nesta seção são os perigos da homogeneização nas interpretações guiadas pelas noções de cultura de massa do mundo moderno. Visto que a materialidade do período está marcada por bens produzidos em massa, uma associação direta à massificação de ideias e à padronização social se mostra atraente em primeira instância, mas conduzir uma análise desta forma significaria, alerta a autora, reafirmar a marginalidade dos grupos emudecidos por uma cultura dominante a eles sobreposta. Entretanto, orientar-se de maneira sensível a estes cuidados na análise é uma questão de posicionamento ético, variando muito na comunidade de arqueólogos. Mas Little mantém sua perspectiva otimista quanto aos sucessos obtidos pela arqueologia socialmente engajada, que não é incompatível com o desenvolvimento econômico almejado pela maioria das autoridades governamentais envolvidas.

Nos nove capítulos reservados à terceira seção, a autora promove o levantamento bibliográfico de uma série de estudos de caso, alguns nos quais esteve diretamente envolvida, para ilustrar diferentes situações enfrentadas por arqueólogos e as soluções interpretativas por eles encontradas. Além de selecionar autores cujo posicionamento teórico está alinhado ao seu próprio, Little direciona suas escolhas aos estudos que deram vozes aos marginalizados, como casos de papéis de gênero, prisioneiros, escravos e trabalhadores pobres, mas também dá espaço a questões inovadoras em recortes tradicionais, como a análise das missões religiosas do período colonial como um tipo de imperialismo que não suprime a imaginação cultural, ou o comportamento de consumo que não está limitado ao modismo e ao grau de riqueza.

Na última seção, a mais sintonizada às propostas da Arqueologia Pública, os oito capítulos finais operam como um manifesto à aplicabilidade social das decisões concernentes ao patrimônio cultural. Em nenhum momento é negada a utilização econômica dos sítios como destinação turística, desde que se mantenha o foco no estímulo ao empoderamento dos membros da comunidade local. Na clara relação de poder que perpassa o controle sobre o passado, Little sobrepõe ao lucro a preservação de determinadas heranças. Alerta, ainda, que o título de "patrimônio" pode incorrer no isolamento de memórias, na exclusão e na invisibilidade de outras porções do passado, conforme se opta pela viabilidade de uma história em lugar de outra, mas caberia à faceta pública da Arqueologia trabalhar na inclusão social dos não representados. 
Porém, mais do que uma função dos acadêmicos e arqueólogos profissionais, deveria ser equipado o próprio público com as ferramentas que o tornaria capaz de refletir criticamente sobre as informações que recebe. Esta seria a função primeira da educação, mas não exime a responsabilidade de uma Arqueologia Histórica sintonizada com as demandas sociais, pois, assim como não se tem por relevante uma história que não nos inclui, não se preserva aquilo que não se conhece.

O livro de Little proporciona uma incursão reflexiva a problemáticas atuais do patrimônio cultural. Embora estabeleça, desde o título, uma ligação transparente com a Arqueologia Histórica, a exposição das ideias se dá de maneira a contemplar as preocupações emergentes nos meios de proteção aos elementos simbólicos do passado. Mais do que isso, pondera sobre a própria conformação dos conceitos que definem os símbolos do passado no presente, com ênfase nas categorias materiais preservadas. É uma leitura rica em dados, com muitos estudos de caso, mas também um exercício de questões e questionamentos ainda abertos ao debate e em constante transformação.

Recebido em outubro de 2012.

Aprovado em maio de 2013. 